\title{
Morphological aspects of tympanic bulla after ventral osteotomy in cats ${ }^{1}$
}

\author{
Aspectos morfológicos da bulla tympanica de gatos após osteotomia ventral
}

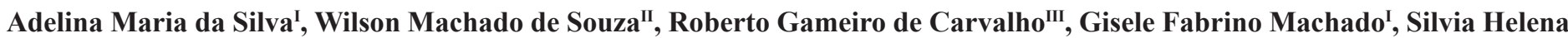 \\ Venturoli Perri ${ }^{\mathrm{IV}}$ \\ ${ }^{I} \mathrm{PhD}$, Assistant Professor, Department of Clinics, Surgery and Animal Reproduction, UNESP, Araçatuba-SP, Brazil. \\ ${ }^{\text {II }} \mathrm{PhD}$, Full Professor, Department of Biosciences, Production and Animal Health, UNESP, Araçatuba-SP, Brazil. \\ ${ }^{\text {III }}$ Master, Assistant Professor, Department of Biosciences, Production and Animal Health, UNESP, Araçatuba-SP, Brazil. \\ IV PhD, Assistant Professor, Department of Biosciences, Production and Animal Health, UNESP, Araçatuba-SP, Brazil.
}

\begin{abstract}
Purpose: To evaluate tympanic bulla healing after experimental ventral osteotomy in cats. Methods: Twenty adult cats were submitted to unilateral ventral bulla osteotomy and divided into two groups: cats of A1 group $(n=10)$ were euthanized at 8 weeks and cats of A2 group ( $\mathrm{n}=10)$, at 16 weeks postoperative. Results: Signs of Horner's syndrome or damage to the inner ear were not found. Open-mouth radiographs taken in the immediate postoperative showed interruption in the contour of the larger compartment of the operated bulla. The result of Mcnemar'test was significant in A2 group $\left({ }^{*} \mathrm{p}=0.0156\right)$. Macroscopic exams revealed that the operated bullae were similar to the normal ones, with preservation of the tympanic cavity. Connective tissue at the osteotomy site of the larger compartment was significantly found in the operated bullae in both groups (McNemar test: A1 p=0.0020*; A2 p=0.0078*). Histomorphometric analyses showed that the connective tissue length at the osteotomy site was shorter in A2 group than in the A1 group (Mann-Whitney test: $\left.\mathrm{p}=0.0021^{*}\right)$. Conclusions: Experimental ventral osteotomy did not alter significantly the tympanic bulla conformation and complete regeneration of tympanic bulla frequently did not occur before 16 weeks of postoperative period.
\end{abstract}

Key words: Ear, Middle. Otitis Media. Cats.

\section{RESUMO}

Objetivo: Avaliar a morfologia da bulla tympanica de gatos após osteotomia ventral unilateral. Métodos: Foram utilizados 20 gatos distribuídos em dois grupos de 10 animais cada, de acordo com o período de observação: A1 (8 semanas) e A2 (16 semanas). Resultados: Nenhum animal apresentou síndrome de Horner ou lesão do ouvido interno. Nas radiografias em projeção com a boca aberta realizadas no pós-operatório imediato observou-se a interrupção do compartimento maior da bulla tympanica operada, resultado significante no grupo A2 (McNemar, $\mathrm{p}=0,0156^{*}$ ). Os exames macroscópicos revelaram que a bulla tympanica operada apresentava conformação semelhante a da bulla tympanica normal, com preservação da cavidade timpânica. Na maioria das bullae tympanicae operadas observou-se a presença de tecido conjuntivo na área de osteotomia. O resultado do teste de McNemar foi significante em ambos os grupos ( $\mathrm{A} 1, \mathrm{p}=0,0020^{*} ; \mathrm{A} 2, \mathrm{p}=0,0078^{*}$ ). Os exames histomorfométricos demonstraram que a extensão de tecido conjuntivo presente no local da osteotomia do compartimento maior era menor nas bullae tympanicae operadas do grupo A2 (Mann-Whitney, $\mathrm{p}=0,0021 *)$. Conclusões: A osteotomia ventral não alterou de maneira significativa a conformação da bulla tympanica. A regeneração total da bulla tympanica geralmente não ocorreu antes de 16 semanas de pós-operatório.

Descritores: Orelha Média. Otite Média. Gatos.

${ }^{1}$ Research performed at Department of Clinics, Surgery and Animal Reproduction, São Paulo State University (UNESP), Araçatuba-SP, Brazil.

\section{Introduction}

Otitis media and polyps are the most common diseases of the middle ear in cats, and their surgical treatment usually consists of ventral tympanic bulla osteotomy. ${ }^{1-5}$ The bulla of the cat differs from that of the dog. It has a septum within the bulla which divides it into two compartments (dorsolateral and ventromedial). These compartments communicate through a fissure on the caudomedial aspect of the smaller compartment, where the septum is incomplete. When the bulla osteotomy is performed, part of this septum must be removed in order to achieve through curettage and adequate drainage of both compartments, without inflicting injury to the structures of hearing and balance or the nerve tracts which cross the middle ear. ${ }^{5,6}$

Increased understanding of the response to ventral osteotomy may help the surgeon to better manage recurrences, reoperations and changes in the middle ear function. The anatomic changes that occur with healing of ventral tympanic bulla osteotomy have been studied in dogs, whose bulla consists of a single compartment. ${ }^{7,8}$ Although the crescent clinical application, we 
did not find experimental studies about this surgery in cats. Therefore, in this study, our objective was to evaluate the morphology of the tympanic bulla after experimental ventral osteotomy in cats by radiographic, macroscopic, histolopathological and histomorphometric exams. Risks of nerve and inner ear damage were also assessed.

\section{Methods}

This study was approved by the Ethics Committee for Animal Research of the São Paulo State University - campus Araçatuba.

\section{Animals and experimental design}

Twenty healthy young adult (aging between 9 and 24 months) mixed breed cats (weighing $3,2 \pm 0,35 \mathrm{~kg}$ ) were utilized. Ten spayed females and 10 neutered males were used. Experimental ventral tympanic bulla osteotomy (Figure 1) was performed at random in either the right or left ear. Animals were divided into two groups, according to the postoperative observation time: cats of A1 group $(n=10)$ were euthanized at 8 weeks and cats of A2 group $(\mathrm{n}=10)$, at 16 weeks postoperative.

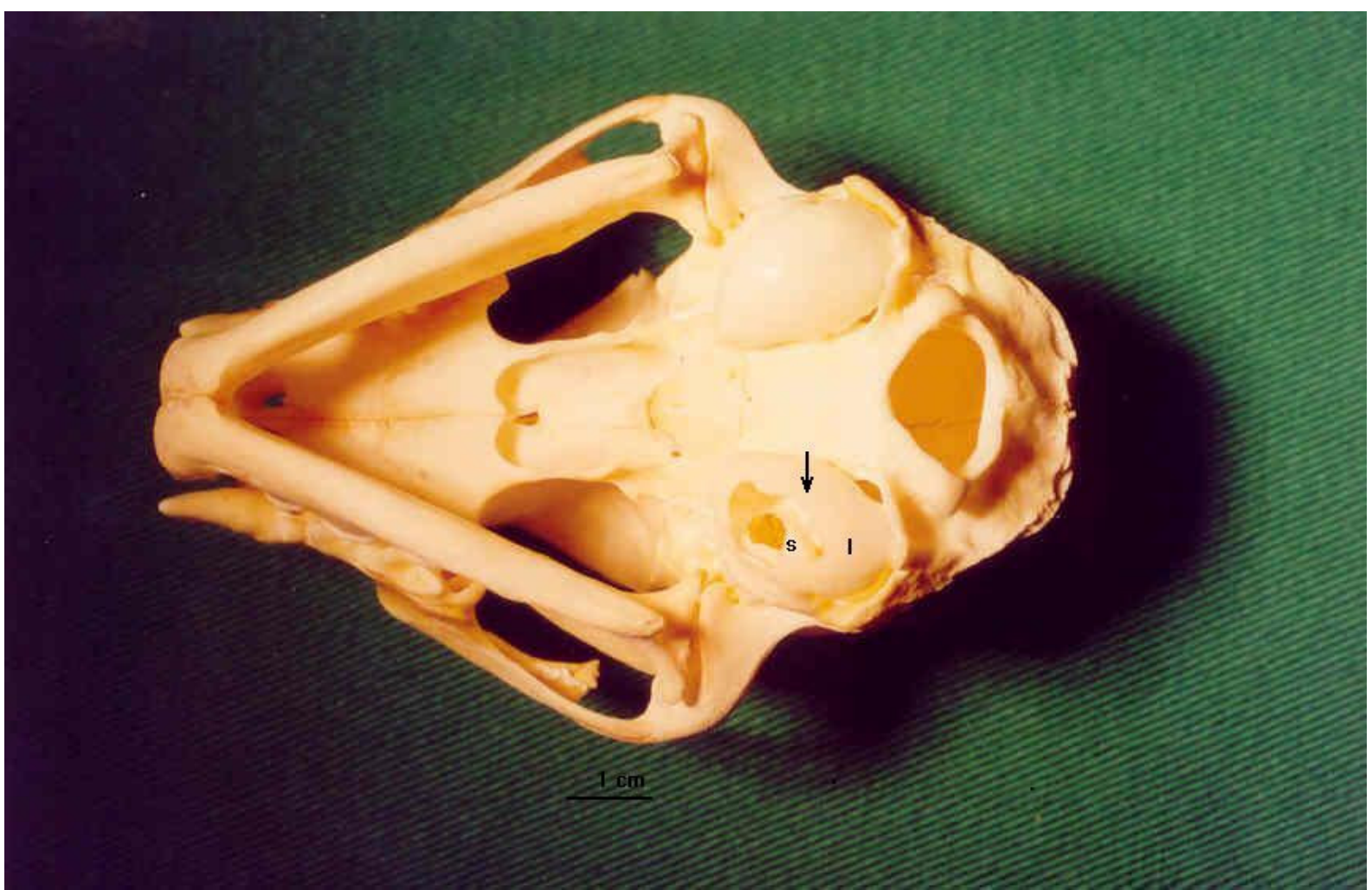

FIGURE 1 - Photograph of a feline skull, showing ventral tympanic bulla osteotomy (arrow). Observe the larger compartment (l) and the smaller compartment (s)

\section{Surgical procedure}

Food was withheld for 12 hours prior to anesthesia. The cats were premedicated with atropine $(0.05 \mathrm{mg} / \mathrm{kg} \mathrm{SC})$ and xylazine $(2 \mathrm{mg} / \mathrm{kg} \mathrm{SC})$. Anesthesia was induced with ketamine $(15 \mathrm{mg} / \mathrm{kg}$, $\mathrm{SC})$, and maintained with tiopental $(5 \mathrm{mg} / \mathrm{kg} \mathrm{IV})$ and fentanil $(0.0125 \mathrm{mg} / \mathrm{kg}$ IM). Lactated Ringer's solution $(10 \mathrm{ml} / \mathrm{kg} \mathrm{IV})$ was administered throughout anesthesia. Enrofloxacin and ketoprofen were administered preoperatively and for 3 days postoperatively.

The ventral cranial and cervical regions were clipped, prepared, and draped under sterile technique. Cats were positioned in dorsal recumbency and a paramedian skin incision was made from the angle of the mandible to the hyoid apparatus. Then, the subcutaneous tissues and the mylohyoideus muscle were incised. The bulla was located by blunt dissection of the digastricus and hyoglossus muscles and identified by palpation. The ventral surface of the tympanic bulla was exposed with a periosteal elevator. The osteotomy was initiated with a $3 \mathrm{~mm}$ diameter pin and enlarged with rongeurs to encompass the entire ventral tympanic bulla floor (circa $10 \mathrm{~mm}$ x $6 \mathrm{~mm})$.

The septum of the bulla was also opened with a 3-mm diameter pin. The tympanic cavities of the two compartments were curetted and irrigated with $0.9 \%$ saline. A $1-\mathrm{cm}$ diameter Penrose drain was placed into the middle ear, exited through a separate stab incision in the skin lateral to the surgical wound and anchored with a suture. Subcutaneous layer was closed with 4-0 poliglactin 910. Skin closure was with 4-0 nylon. The Penrose drain was removed after 3 days and skin sutures removed on day 7 . 


\section{Postoperative observations and radiographs}

After bulla osteotomy the cats were monitored for clinical signs of Horner's syndrome, damage to the inner ear and hypoglossal nerve paralysis.

Radiographs were performed immediately after surgery and at the end of the study, i.e., after 8 (A1) and 16 (A2) weeks postoperative. The oblique lateral, ventrodorsal, and open-mouth views of the tympanic bullae were taken.

Macroscopic analysis, histolopathology and histomorphometry

The cats were euthanized with tiopental ( $45 \mathrm{mg}$ / $\mathrm{kg}$ IV) after 8 (A1 group) and 16 weeks (A2 group) postoperative. The normal and operated tympanic bullae of each cat obtained at necropsy were fixed in $10 \%$ formalin and decalcified in an aqueous solution of 5.66 formalin $10 \%$ to 1 of nitric acid (v/v). Then, each of these bullae was divided into two segments longitudinal to the larger axis of the osteotomy. The specimens were processed routinely and thin sections were made and stained with hematoxylin-eosin for microscopic evaluation.

For the histomorphometry, the images of sections were captured using a Leica DMLS microscope connected to a Sony Power HAD 3 CCD video camera, and transferred to an image analyzer (Leica QWIN). In this planimetric study, the connective tissue length at the osteotomy site was measured in $\mu \mathrm{m}$. The largest value obtained from each cat was included in data analysis.

\section{Statistical analysis}

Non-parametric tests were utilized for the data analysis, taking into consideration the nature of the variables. McNemar's test ${ }^{9}$ was used to compare data between operated bullae and contralateral unoperated bullae. Mann-Whitney's test ${ }^{10}$ was used to compare histomorphometric data between groups A1 and A2. Significance was set at $\mathrm{p} \leq 0.05$.

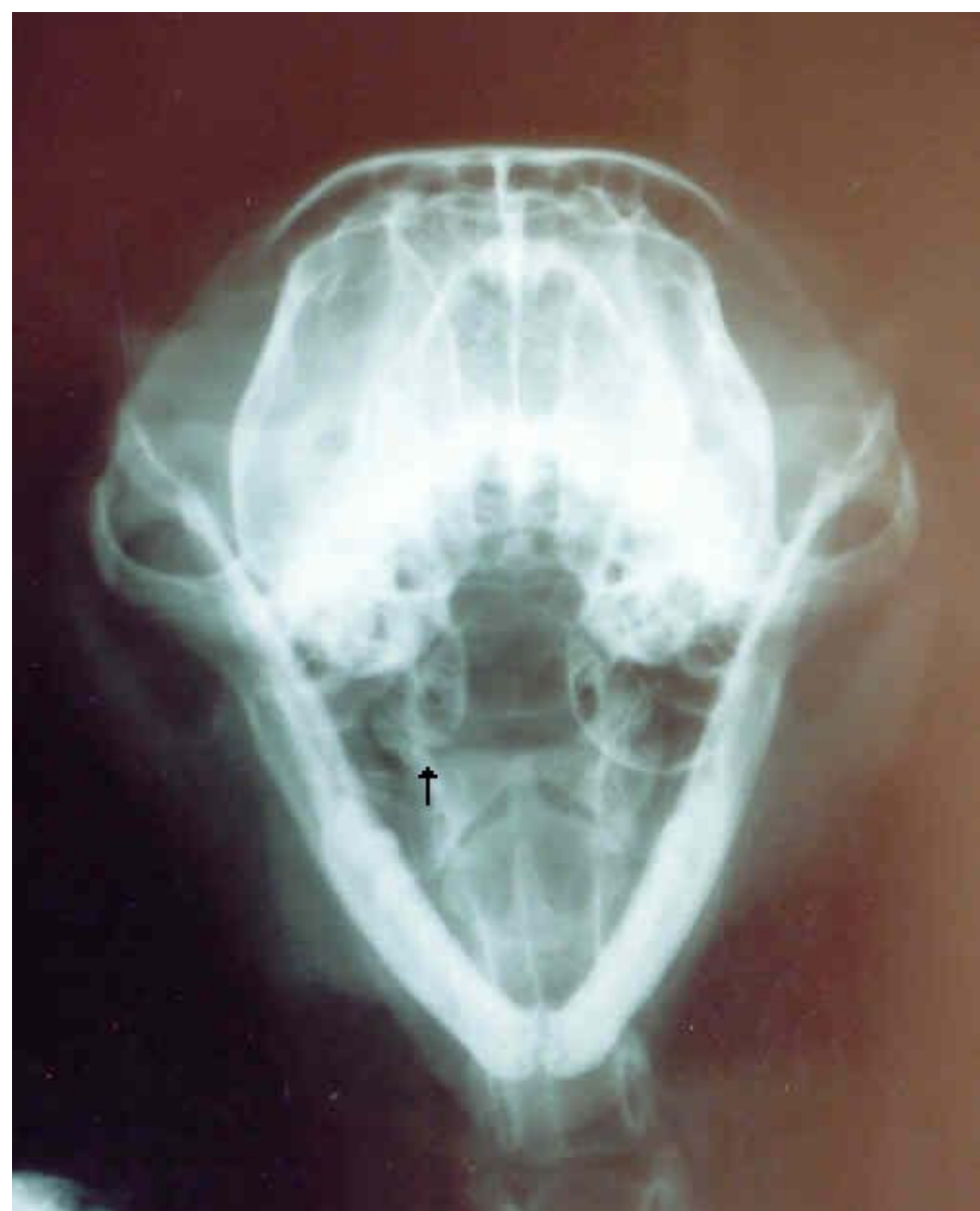

FIGURE 2 - Radiograph in open-mouth projection of cat 10 of group A2 taken immediately postoperative. Observe the interruption in the contour of the larger compartment of the operated bulla (arrow)

\section{Results}

None of the operated cats showed clinical signs indicative of Horner's syndrome or damage to the inner ear. In addition, we did not observe damage to the hypoglossal nerve in any of the animals.

The open-mouth radiographs taken immediately after surgery showed an interruption in the contour of the larger bulla compartment in 4 operated cats of the A1 group and 6 from the A2 group (Figure 2; McNemar's test, ${ }^{*} \mathrm{p}=0.0156$ ). The interruption in the contour of the smaller compartment was found in only one cat (A1 group). The open-mouth radiographs taken at the end of the study showed interruption in the contour of the bulla smaller compartment in one cat of each group (A1 and A2). These radiographs showed also flatness in the contour of the larger compartment of the operated bulla of one cat from the A1 group and two cats from
A2. The oblique lateral radiographs showed interruption in the contour of the larger compartment in 3 cats from A1 group and in one cat from A2 immediately postoperative and in one cat from each group at the end of the study.

The macroscopic exam revealed that the operated tympanic bullae were similar to the normal ones, with preservation of the tympanic cavity in both A1 and A2 groups. In the A1 group, 7 operated bullae presented a slight protuberance in the inner surface of the larger compartments, and the other 3 bullae had the operated area pink in color. Also in the A1 group the orifice done in the bone septum was still open in 2 cats. In A2 cats the slight protuberance in the inner surface of the larger compartment was present in all ten tympanic bullae (Figure 3). The orifice made in the bone septum remained open in 3 cats. 


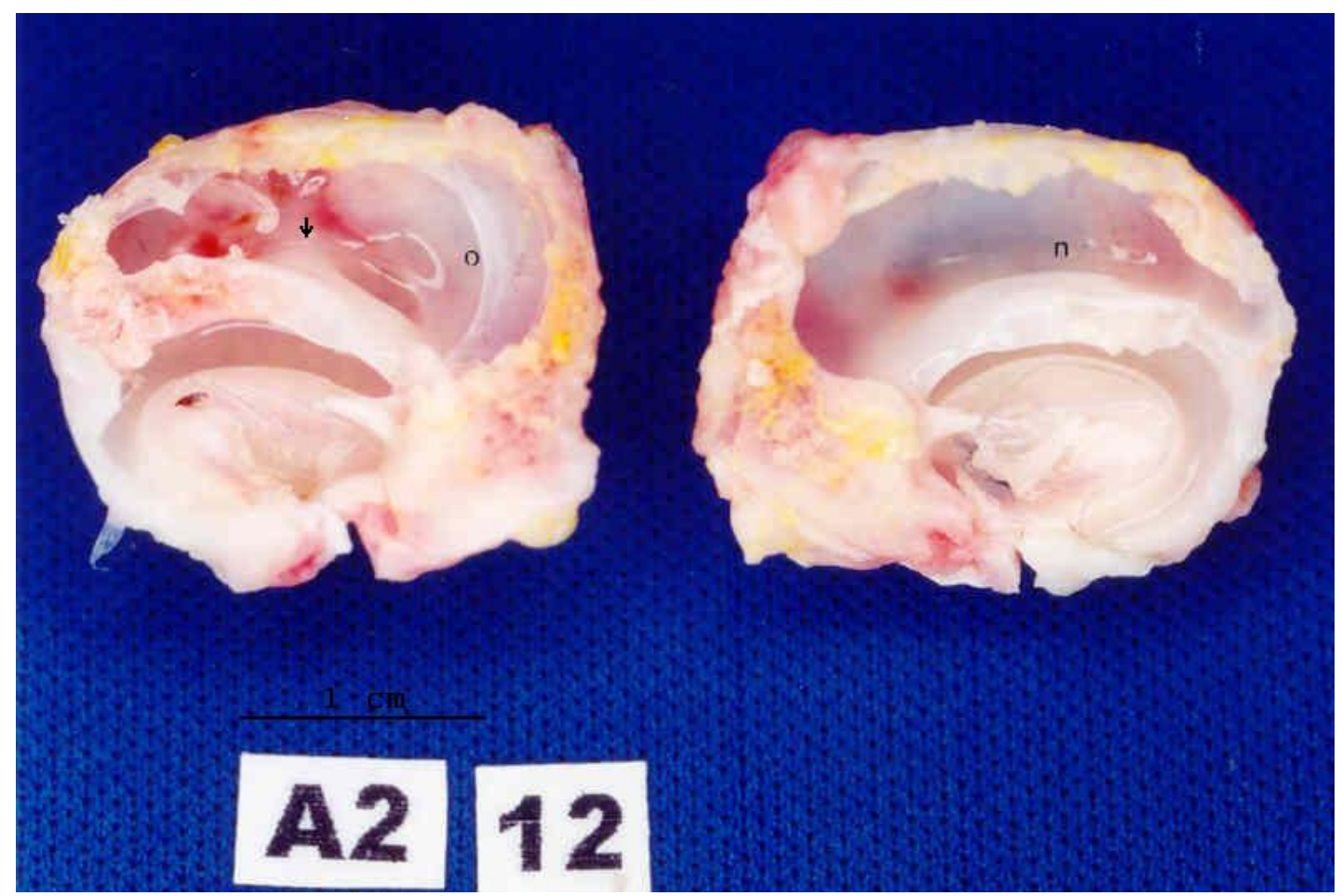

FIGURE 3 - Macroscopic aspect of the tympanic bullae of cat 12 of group A2. The concavity of the operated bulla (o) is similar to the normal one (n). Observe the light protuberance in the inner surface of the larger compartment (arrow)

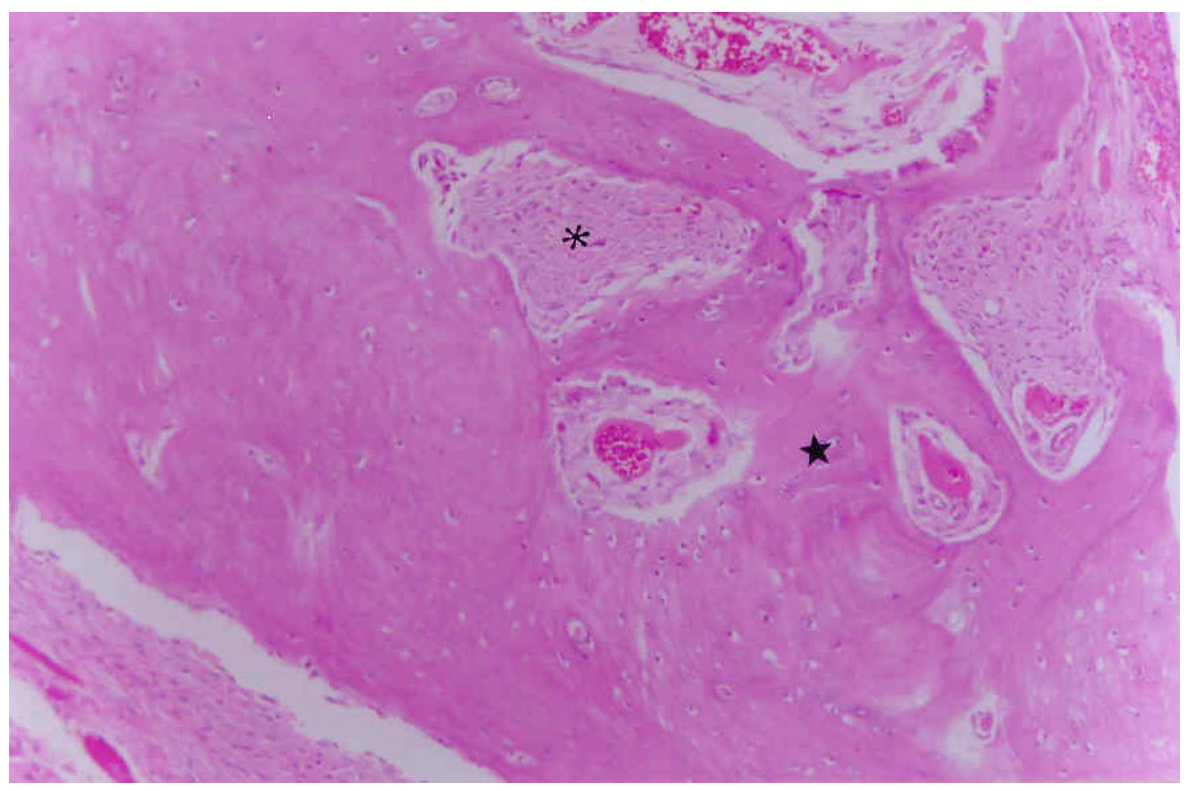

FIGURE 4 - Photomicrograph of the operated tympanic bulla of cat 8 of group A2. Bone tissue $(\star)$ and connective tissue $(*)$ are present at the osteotomy site, indicating intramembranous ossification. (HE, 200x)
Connective tissue was detected in 9 and 7 operated bullae, from A1 and A2 groups, respectively. The result of McNEMAR's test was significant for both groups $\mathrm{A} 1\left(\mathrm{P}=0.0020^{*}\right)$ and A2 $\left(\mathrm{P}=0.0078^{*}\right)$. The osteotomy site was filled with connective tissue in most of the histological sections of the operated tympanic bullae of the A1 group, and areas of bone inside this connective tissue were observed in the sections of 7 cats. Thickening of the osseous wall due to lamellae deposition on both inner and outer surfaces of the larger compartment occurred mainly at the edges of the osteotomy site. Osteoblasts were common in these ossification areas. Thickening of the inner septum by lamellae deposition was also observed. Histological analysis revealed that the smaller compartment was lined with ciliated pseudostratified columnar epithelium with numerous goblet cells. The results found from histological examination of the operated tympanic bullae of A2 cats (Figure 4) were similar to those found for A1 cats. However, the osseous thickening of the larger compartment was more prominent in some animals. Complete regeneration of the larger compartment and the osteotomy site filled with woven bone was found in one bulla from A1 group and 3 bullae from A2 group. The length of connective tissue at the osteotomy site $(\mu \mathrm{m})$ was shorter in the A2 group than in A1 (Mann-Whitney's test, $\mathrm{P}=0.0021^{*}$; Table 1 ). 
TABLE 1 - Connective tissue length in $\mu \mathrm{m}$ at the osteotomy site of bullae of group A1 ( 8 weeks of postoperative) and group A2 (16 weeks of postoperative) measured by the histomorphometry

\begin{tabular}{lcc}
\hline Statistic & Group A1 & Group A2 \\
& 0 & 0 \\
& 1935 & 0 \\
& 2680 & 0 \\
& 3130 & 134 \\
& 3290 & 148 \\
& 3834 & 211 \\
& 4899 & 325 \\
& 5383 & 2007 \\
& 5756 & 2346 \\
& 5899 & 2430 \\
\hline Mean & 3680.6 & 760.1 \\
Standard deviation & 1876.3 & 1046.1 \\
Median & 3562.0 & 179.5 \\
\hline Mann-Whitney's & test $\mathrm{P}=0,0021^{*}$ & \\
\hline
\end{tabular}

\section{Discussion}

Retrospective clinical reports have indicated a high prevalence of Horner's syndrome after ventral bulla osteotomy (about 58 to $95 \%)^{3-5}$ Horner's syndrome, classically presenting with miosis, prolapse of the third eyelid and ptosis of the eyelid, results from direct damage to the postganglionic sympathetic fibers coursing to the eyes and eyelids where they pass through the tympanic cavity. ${ }^{6,11}$ No operated cats of our study showed clinical signs of Horner's syndrome, possibly because during surgery the inner septum was carefully perforated but not removed.

Clinical signs (nystagmus, ataxia and head tilt) indicative of damage to the inner ear structures were not observed in any of the 20 cats studied, probably because curettage of the promontory was avoided. Similarly, only one animal showed this complication in one report series in which 23 cats with nasopharyngeal polyps and otits media were treated with ventral tympanic bulla osteotomy and polyp traction. ${ }^{4}$ A contrasting result was reported by Faulkner and Budsberg ${ }^{3}$, who found 5 out of 12 cats submitted to ventral osteotomy showing clinical signs of damage to the inner ear. However, in this later study the cats had otitis media and externa and the polyp was present in the external ear canal. Another report ${ }^{5}$ showed a low incidence of damage to the inner ear (2 of 19 cats followed up in the postoperative). An important feature observed in this report $^{5}$ was that otitis interna was evidenced in 8 of 19 cats with middle ear disease (otitis media, polyp or neoplasia) before surgery.

In the present study, the hypoglossal nerve was easily identified coursing along the lateral surface of the hypoglossal muscle. Although this nerve was stretched during dissection and soft-tissue retraction, tongue paralysis did not occur in any case. This same result has been previously reported. ${ }^{3-5}$

No abnormalities were found in the ventrodorsal radiographs of operated and normal bullae in the immediate postopera- tive period and at the end of the study of each group (A1 and A2). This abnormalities were probably masked by the overlap of cranial bones as described in a previous report on dogs submitted to experimental unilateral ventral osteotomy. ${ }^{8}$ On the other hand, openmouth and oblique lateral radiographs afforded better visualization of the tympanic bulla, detached from the other cranial bones. This allowed detection of some features, but only in some of the oblique lateral radiographs. This is inconsistent with a previous experimental study in dogs, in which the interruption in the contour of the tympanic bulla was seen more frequently on radiographs done in oblique lateral view. ${ }^{8}$ But the adequacy of the radiographic plane may be related to bulla anatomy, and since the tympanic bulla of the cat seems shallower than that of the dog, the open mouth radiography may better reveal its features. The open-mouth radiographs taken immediately after surgery showed an interruption in the contour of the larger bulla compartment in 4 operated cats of A1 group and 6 of the A2 group (Figure 2). Flatness or interruption in the contour of this same compartment was observed only in some radiographs taken at the end of the study. Similar results were found in dogs submitted to experimental ventral osteotomy. ${ }^{8}$ Bulla radiography is often useful in evaluating middle-ear diseases. Radiographic evidences of bulla diseases include densities in the tympanic cavity and thickening of the bulla wall..$^{1-5,12}$ In the present study, increased density of the tympanic cavity was not found in any radiograph performed 8 (A1 group) or 16 (A2 group) weeks after ventral osteotomy, indicating that the operated bulla remained filled with air and did not contain tissues or secretions. Thickening of the wall of the bulla was not observed either. Previous reports in dogs found similar results. ${ }^{8,13}$

The macroscopic exams revealed that the concavity of the operated bullae were similar to the normal ones, with preservation of the tympanic cavity. Just a slight protuberance in the inner surface of the larger compartment was detected in most of the operated bullae (Figure 3). This disagrees with the results of a previous 
experimental study in dogs, in which the entire ventral tympanic bulla floor was removed. ${ }^{7}$ These authors observed that partial or complete obliteration of the tympanic cavity occurred in most of the dogs, and detected reduced auditory sensitivity in one of them (evaluated by brain stem auditory evoked potentials) probably because the bone proliferation impinged on the auditory ossicles or vestibular window. In another experimental study in dogs, the bulla osteotomy was restricted to a small area of the ventral floor and the normal volume of the tympanic cavity was almost preserved. ${ }^{8}$ In our study with cats, the osteotomy of the larger compartment had to be wider to give access to the inner septum. But because lateral walls were preserved, bone proliferation was slight and did not obliterate the tympanic cavity. The bone septum orifice was closed in most of the tympanic bullae of both A1 and A2 groups. However, the communication between the two compartments of the middle ear, naturally present in the caudomedial aspect of the smaller compartment, near the coclear window, was not affected by the osseous proliferation because this occurred only at the osteotomy site in both groups.

The histological exams revealed that complete postoperative regeneration of the tympanic bulla did not occur frequently before 16 weeks, but connective tissue was present in most of the operated bullae of groups A1 and A2. The rate of regeneration was quite variable among the operated cats. High cellular loose connective tissue was detected at the osteotomy site in earlier stages. Foci of woven bone in the connective tissue were present in many sections, indicating regeneration of the tympanic bulla by intramembranous ossification. Bony proliferation was observed only in more advanced stages. The osteotomy site was filled with woven bone in the cats that presented complete regeneration of the tympanic bulla. These results are compatible with previous reports in dogs. ${ }^{7,8}$ Despite the variability, the connective tissue length at the osteotomy site, measured by histomorphometry, was shorter in the A2 group than in the A1 group (Table 1). These results showed a significant trend for complete regeneration. As a concluding remark, ventral osteotomy does not alter significantly the tympanic bulla con- formation and complete regeneration of tympanic bulla usually requires more than 16 weeks from the postoperative period.

\section{References}

1. Ader PL, Boothe HW. Ventral bulla osteotomy in the cat. J Am Anim Hosp Assoc. 1979; 15:757-62.

2. Bradley RL, Noone KE, Saunders GK, Patnaik AK. Nasopharyngeal and middle ear polypoid masses in five cats. Vet Surg. 1985;14:141-14.

3. Faulkner JE, Budsberg SC. Results of ventral bulla osteotomy for treatment of middle ear polyps in cats. J Am Anim Hosp Assoc. 1990;26:496-9.

4. Kapatkin AM, Matthiesen DT, Noone KE, Church EM, Scavelli TE, Patnaik AK. Results of surgery and long-term follow-up in 31 cats with nasopharingeal polyps. J Am Anim Hosp Assoc. 1990;26:387-92.

5. Trevor PB, Martin RA. Tympanic bulla osteotomy for treatment of middle-ear disease in cats: 19 cases (1984 -1991). J Am Vet Med Assoc. 1993;202:123-8.

6. Little CJL, Lane JG. The surgical anatomy of the feline bulla tympanica. J Small Anim Pract. 1986;27:371-8.

7. Mcanulty JF, Hattel A, Harvey CE. Wound healing and brain stem auditory evoked potentials after experimental ventral tympanic bulla osteotomy in dogs. Vet Surg. 1995;24:9-14.

8. Silva AM, Fagundes DJ, Taha MO, Goldenberg S, Machado GF, Juliano Y, Novo NF. Aspectos morfológicos da bulla tympanica de cães após osteotomia restrita ventral e lateral. Acta Cir Bras. 2001;16:243-50.

9. Remington RD, Schork MA. Statistics with applications to biological and health sciences. Englewood Cliffs: Prentice Hall; 1970.

10. Siegel S, Castellan Jr NJ. Nonparametrics statistics. 2ed. New York: McGraw-Hill; 1988

11. Greene GE, Oliver Jr JE. Neurologic examination. In: Ettinger SJ. Textbook of veterinary internal medicine. 2ed. Philadelphia: Saunders; 1983.

12. Lane JG, Orr CM, Lucke VM, Gruffydd-Jones TJ. Nasopharyngeal polyps arising in the middle ear of the cat. J Small Anim Pract. 1981;22:511-22.

13. Holt DE, Walker L. Radiographic appearance of the middle ear after ventral bulla osteotomy in five dogs with otitis media. Vet Radiol Ultrasound. 1997;38:182-4.

\section{Correspondence:}

Adelina Maria da Silva

São Paulo State University (UNESP)

Department of Clinics, Surgery and Animal Reproduction

Rua Clóvis Pestana, 793

16050-680 Araçatuba - SP Brazil

adelinasilva@uol.com.br

Conflict of interest: none Financial source: FAPESP

.

Received: December 15, 2008

Review: February 17, 2009

Accepted: March 24, 2009

\section{How to cite this article}

Silva AM, Souza WM, Carvalho RG, Machado GF, Perri SHV. Morphological aspects of tympanic bulla after ventral osteotomy in cats. Acta Cir Bras. [serial on the Internet] 2009 May-Jun;24(3). Available from URL: http://www.scielo.br/acb 